University of Nebraska - Lincoln

DigitalCommons@University of Nebraska - Lincoln

$12-2015$

\title{
North Shore: A Natural History of Minnesota's Superior Coast
}

Janet R. Koeugh

United States Environmental Protection Agency

Follow this and additional works at: https://digitalcommons.unl.edu/tpn

Part of the Biodiversity Commons, Botany Commons, Ecology and Evolutionary Biology Commons, Natural Resources and Conservation Commons, Systems Biology Commons, and the Weed Science Commons

Koeugh, Janet R., "North Shore: A Natural History of Minnesota's Superior Coast" (2015). The Prairie Naturalist. 66.

https://digitalcommons.unl.edu/tpn/66

This Article is brought to you for free and open access by the Great Plains Natural Science Society at DigitalCommons@University of Nebraska - Lincoln. It has been accepted for inclusion in The Prairie Naturalist by an authorized administrator of DigitalCommons@University of Nebraska - Lincoln. 
North Shore: A Natural History of Minnesota's Superior Coast. Chel Anderson and Adelheid Fischer. 2015. University of Minnesota Press, Minneapolis, Minnesota, USA. 619 pages. \$39.95 (cloth). ISBN: 978-0-8166-3232-9.

Many readers of The Prairie Naturalist have lived along or visited Lake Superior's coast. Like me, you have probably wondered about the geology and history of this beautiful and dramatic feature of northeastern Minnesota. Chel Anderson and Adelheid Fischer have written an accessible book that comprehensively describes the history and geology of the coast, surrounding highlands, and Lake Superior itself. In addition, the authors have provided fascinating subchapters on some of the most interesting species that are key elements of the region.

This rather large but beautiful book is arranged in five major chapters that cover the dominant geological units of the North Shore: Headwaters, Highlands, Nearshore, Lake Superior, and Islands. This is a natural division that allows for a coherent description of the unique geological, floristic, and anthropogenic characters of each important ecosystem. Each chapter begins with an overview of the geology that fashions the ecosystems. The Headwaters chapter, for instance, moves from the glacial history to the interplay of land and water that shaped the dry forests, headwater streams, lakes, and wetlands, with special attention to the role that the American beaver (Castor canadensis) played in shaping the headwater ecosystems. Lake Superior is described in the context of the multiple glacial advances and retreats and the Midcontinent Rift System that developed into this highly variable and largest lake in North America. The narrative summarizes considerable technical information but at a level that is accessible to both experts and laypersons.

Following the general background information, each chapter includes interesting subchapters that reveal the ecological richness of the North Shore through accounts of a few species that inhabit each of the five areas. The subchapters of the Highlands chapter, for instance, discuss, the damage done to the forest by invasive earthworms; the secret life of salamanders that inhabit the forests and wetlands; a most interesting discussion of plant galls; the relationship between American black bears (Ursus americanus) and native (but uncommon) oak (Quercus spp.) trees; and a delightful section on the star-nosed mole (Condylura cristata). Through these species accounts, we learn a great deal about the overall ecology of the North Shore Highlands. The Islands of Lake Superior are no less diverse and rich in history and ecology. Half of the subchapters in the Islands chapter discuss Isle Royale, its boreal chorus frogs (Pseudacris maculata), and its really fascinating history of large mammals. Most readers are likely aware of the long-term research on the relationship between populations of moose (Alces alces) and gray wolves (Canis lupus) on Isle Royale, and this subchapter covers that very well. However, most of us are not aware that woodland caribou (Rangifer tarandus caribou), Canada lynx (Lynx canadensis), and snowshoe hare (Lepus americanus) were the original mammalian triad of Isle Royale until around 1920, when caribou were extirpated from the island through hunting, and the lynx followed suit. Moose and wolves are fairly recent immigrants (arriving around 1905) in the ecosystem. The authors provide a very readable account of Native American uses of Isle Royale and the later dominance by EuroAmericans. Both groups exploited the copper deposits, forest timber, and fisheries. I especially enjoyed this chapter, overall, as it provided an interesting in-depth description of the history of Isle Royale. This chapter also briefly mentions the Susie Islands, which are less well-known than Isle Royale but still rich in flora and fauna.

As a wetland ecologist, I especially enjoyed the chapter on the Nearshore of Lake Superior. I would have liked more discussion about the ecology of coastal wetlands, which are interesting but limited along the North Shore due to the rocky shore and steep river valleys. A subchapter "Hay Pickers and Grass Gatherers: Botanical Exploration along the Lake Shore" provided an account from the mid-1800s, when Louis Agassiz, his students, and other naturalists started a long period of discovery of the plant diversity along the shoreline. This led to discoveries of disjunct arctic-alpine plant species that make this ecosystem so special. If you are one of those people who loves to walk along the rocky shore, looking into wet crevasses for tiny but hardy flowers, mosses, and lichens, you will enjoy this chapter!

The authors spend considerable space and information on the interactions between humans and the North Shore ecosystems, reminding us that this region had extensive past history of logging, trapping, fishing, mining, and some agriculture. In fact, the forest ecosystem has been dramatically altered by the removal of white pine (Pinus strobus) during the area's logging heyday. The Highlands chapter provides an engaging section of the history of settlement, encouraged by the Minnesota Commissioner of Immigration in the mid-1600's. Settlement, along with mining and logging and associated fire, removed most of the old-growth forest including the dominance of white pine and yellow birch (Betula alleghanien$s i s)$. The authors provide illustrative pictures of various types of human commerce and settlement, which provide important background to understanding the forest we have today, largely dominated by balsam fir (Abies balsamea), poplar (Populus spp.), white pine, and paper birch (Betula papyrifera). Human history is mixed nicely with the narrative on the geology and ecology of the region, making for engaging reading. The authors also provide a list of additional reading references after each subchapter, helpful to those who wish to delve farther into a subject.

This is a hefty tome that is provided at a very reasonable price; the chapters and subchapters are extremely rich in information that encourage one to learn a great deal by stepping through the ecosystems of the North Shore.- Janet $R$. Keough, Associate Director for Science (retired), Office of Research and Development, U. S. Environmental Protection Agency, Duluth, Minnesota 55803, USA. 